\title{
Organ Transplantation and Relevant Law
}

\author{
Jinguo Wang \\ Department of Urology \\ The First Hospital of Jilin University \\ Changchun, China \\ wangjinguolily@163.com
}

\author{
Na Wang* (corresponding author) \\ Department of Anesthesiology \\ The First Hospital of Jilin University \\ Changchun, China \\ wangna080613@163.com
}

\begin{abstract}
It is a very realistic subject to establish a scientific and rational legal system, especially the criminal law system to limit organ transplantation which is a new technology in the proper purpose, but objectively not inhibit it developing, in order to prevent the abuse of human organs and the crime associated with human organs. On the basis of the current literature, we analyze the characteristics of the present crimes related to organ transplantation and provide some advises, such as clearly defining the crime, improving the penalty efficiency and increasing the cost of crime directly.
\end{abstract} crime

Keywords—organ transplantation; law; system construction;

\section{INTRODUCTION}

The rapid development of organ transplantation brought the Gospel to people enhance public health benefits. Is one of the countries to carry out the organ transplant earlier in our country, is also one of the organ transplant technology progress relatively quickly. In recent years, the development of organ transplantation in our country is especially rapidly, the scale is growing. Abroad in the field of criminal law protection organ transplantation, organ transplantation is clear, the criminal law protection act concept clear, tight logic, a wide range, is both the countries concerned about the livelihood of the people of organ transplantation, have explained the "nationalism" to "humanistic" "modernization" of the criminal law of the evolution of criminal law developing trend, also to strengthen the protection of the criminal law for transplants. Of organ transplantation in our country law research and legislation is almost in a blank state, this led to some parts of the human organs in our country is abused, while some crime on organ transplantation also occur frequently in our country.

\section{THE CURRENT STATUS OF ORGAN TRANSPLANTATION}

According to the national ministry of health statistics, at the end of 2008, China had accumulative organ transplant more than 550000 cases, among them, more than 10000 cases of liver transplantation and more than 500000 cases of renal transplantation. In terms of quantity, organ transplantation in China is second only to the United States, ranking second in the world.

However, although the medical practice in terms of organ transplantation in China has been far ahead in the world, but with such crimes have serious social harmfulness, in most countries, the buying and selling human organs and relevant commercial operation has a corresponding conviction and sentencing, such as the UK human organ transplantation law, the crime of commercial trade in human organs, organ transplants, Japan stipulated the crime of illegal sale of organs, in order to profit but illegal for others to implement organ transplantation and engaged in intermediary crime and the crime of commercial trade in human organs.

Chinese officially issued and implemented the human organ transplant ordinance, the regulations to the eight basic principles, including voluntary, informed consent, access to technology, fair and just, the commercialization, and decide, etc., and the implementation of organ transplant medical institutions, a certification system, but for an organ transplant in the process of crime, such as illegal buying and selling human organs act, the regulations are banned, but not provided the corresponding charges in the criminal law, and not of this kind of crime shall be investigated for criminal responsibility according to law. In this view, China's legislature should draw lessons from foreign legislative experience, combined with the reality of our country to perfect relevant criminal legislation as soon as possible, in order to effectively combat this kind of crime, criminal law to punish the crime in our country, the purpose of protecting people [1].

The legal attribute of human organs, i.e., whether human organs for criminal law is to protect human organ transplantation have to face a problem, because the legal attribute of human organs will directly decide some migration behavior, including criminal liability, a series of legal responsibility. To steal the human organ transplant, for example, if we see human organs as objects, this behavior is clearly theft crime constitution. If we define human organs is a kind of personality right, then the behavior is not conform to the crime of larceny [2].

\section{THE LEGAL DEFINITION OF HUMAN ORGANS}

For the question of human organs legal attribute, there exist four different theories: some people support the theories that the body's tissues or organs as part of the civil law on the matter. The organization of China civil code draft proposal is adopted in this opinion, the "recommendations". Two characters, the think to whether human organs and human phase separation is bounded, belong to the category of people before separation, after the separation of content. Scholars in Taiwan history is wide the teacher thinks, of the living body may not be used as the res, because in the body of the legal rights is a person, if human body tissues or organs as the right to mark, is contrary to this principle. But when the body tissues 
or organs after the separation of nature and the human body, he's not personal, should be legal, before all of the tissues or organs become holder, can be in accordance with the meaning of the holder for disciplinary action.3, the category of people said that the said that the body's tissues or organs, not on the res, no matter whether it is separating belongs to the category of people with the human body [3].

The body's tissues or organs to do a part of the body do not have the property line, this point of view as the foundation, the body's tissues and organs shall belong to the category of body weight and mark of property rights is not." And as a natural person shall have the right of personality right is one of the important basic meanings of body weight and the request is to protect the integrity of the natural person body, all the destruction of the natural person body integrity is considered to constitute a violation of the right of natural person body". Limited personal category, the theory says that a natural person of tissue or organ is not on the res, but right to the lord which have disciplinary right under the body to a certain extent. Legal sense refers to the legal relationship of the subject, on the production and living of objective entities.

The content is the premise, all have the entities are not legal sense. Human tissues or organs as a natural part of the body, with naturalness and personality two attributes: 1, naturalness, with tissues and organs is one of the natural person's natural attributes and physical characteristics. From the point of the origin of the body's tissues and organs, they are the result of natural law role, rather than artificially created.

In other words, the body's tissues and organs is not in man's will transfer and transfer properties. Based on the property of the body's tissues and organs without harm to the health of the people life, is it can be a natural person with physical separation, and in medicine is feasible. 2, personality and body part of the body's tissues and organs is a natural person, the natural person is the main part of the social relations, the natural person with personality attributes, which attributes embodied the subjects of natural persons and social relations in the social status of acknowledged that consumed by the admitted that won't because of the death of a natural person, also won't because the body's tissues and organs and phase separation and death the human body. On the contrary, in the tissues and organs and separating the human body or the main body, after death the admitted that still exist.

The body's tissues and organs of the attribute determines the natural person in dominate its tissues and organs must receive the ethical, moral and legal aspects of constraints. The four kinds of view, the author agrees with the last one. About the nature of the human body tissues and organs and legal attribute, the author believes that the body's tissues and organs is a kind of has both natural and objective entities, are neither legal nor a legal matter, but a kind of in between "quasi" should be protected by law. Naturalness and are two basic properties of the body's tissues and organs, and the body's tissues and organs of the two kinds of attribute determines the disciplinary right of the natural person is limited to its, its reason is that the body's tissues and organs as a "quasi", as the main legal relationship with the person has the essential difference between, and as the legal relationship object exist some similarities, it's for the body's tissues and organs become the object of legal relationship provides a legal basis. However, although the body's tissues and organs can become the object of legal relation, but because of its itself as the main legal relationship with the people of the composition of the personality traits of are not separated from the original subject of disappear, on the contrary, " the personality traits in donor organs transplanted into another subject before still exist, and become the difference between human organs and content was an important aspect in the eyes of the law" [4]. It determines everything for this kind of disposition to be certain limits, any violation of its behavior can't violate the act of property rights in accordance with the processing. In the field of criminal law, the body's tissues and organs of the nature of the "content", directly determines everything for this kind of "quasi" infringement behavior can't treat as the same in accordance with the "criminal law" in the provisions of the property crime such as robbery, theft to pursue the perpetrators of criminal responsibility.

\section{CRIMES ASSOCIATED WITH ORGAN TRANSPLANTATION}

Crime is the behavior that is harmful to the serious social. "Social harmfulness is the essence of criminal property, is a basic content" function of the definition of crime and in terms of its legal nature, crime is a serious violation of laws to protect the legitimate interests of, or constitute a threat of serious violation. Therefore, our country criminal law stipulated: "all harm national sovereignty, territorial integrity and security, divide the country, subversion of the people's democratic dictatorship regime and overthrow the socialist system, the destruction of social order and economic order, property, state property or working people collective all infringe on their citizen's private property, infringing upon the citizen's personal rights, democratic rights and other rights, and other anti-social behavior, in accordance with the law shall be punished by criminal law, is a crime". So crime should meet the following three basic characteristics: 1 , the serious social harmfulness; 2 , the criminal illegality; 3 , the penalty as punishment. In these three characteristics, "severe social harmfulness is the essential feature of crime has the decisive significance"; Organ transplantation crime as a new type of crime also should have the above three characteristics. But, because of organ transplant technology was in recent years developed a kind of medical technology, national regulation of criminal legislation has not yet been mostly, so the organ transplant crime also had not been exposed. In this view, it is delivered that the part of organ transplant technology related behavior is defined as a crime, mainly due to its serious social harmfulness and punishment when the penalty, that is, it is a serious harm to society, should be punished by law. What contained different sizes according to our press charges to criminal crimes and the division of a crime, crimes should belong to organ transplantation. This paper defines it as on the implementation of the relevant units and individuals related to human organ transplantation of various serious anti-social behaviors [5].

\section{A. The characteristics of crimes}

Criminal object, the object of the crime is the normal order of medical supervision and the personality of others method. 
Organs of state as a social management, responsible for the supervision and management of various medical behavior, maintain normal medical order, guarantee social responsibility is pending, in the ways, organ transplants of criminal behavior person seriously violated state regulation of medical institutions in order. On the implementation of crime is directly to the human body, organ transplantation is usually direct invasion to the victim's right to life, the right to health, damage the body integrity.

Crime objective aspect, behavior person to implement the illegal behavior of organ transplant or other illegal behavior associated with organ transplantation. For organ transplant crime, the objective aspect requires the offender must implement the illegal behavior or organ transplantation is associated with organ transplantation of other serious antisocial behavior. The major form of this kind of crime, illegal buying and selling human organs and illegal harvesting the behavior of human organs, such as ACTS of illegal use of the body, illegal organization sell human organs, the behavior of forced selling human organs and illegal organ transplant surgery, etc.

Crime subject, the crime contains both the main body, generally also contain special subject. Practice, class crime main organ transplantation has realized three forms: (1) the general subject of organ transplantation of crime. Source of this kind of crime is mainly due to the organs, which caused by the deficiency in the whole organ transplant class represents a significant proportion of crime. Because the proportion of supply and demand of serious imbalance, so that the business value of the human organs rise greatly, under the lure of high profits, some criminals dared to take risks, to sell, selling, stealing, cheating, or pluck others organs, and in order to obtain organ and hurt others life. (2) to doctors as the main body to implement this kind of crime. Doctors, for example, in order to implement and forced to gather the vegetative organ transplantation, the mental patient organ, or for organ transplants and steal the organs of the dead. (3) the unit as the main body of this kind of crime. Among the whole organ transplant type of crime, crime, share not to play, but the harm is extremely serious.

Medical and health unit, for example, companies or other entities, in order to get high profits perform illegal harvesting, supply, smuggling of human organs and organ transplant surgery without permission, etc. It is not hard to see, organ transplantation class crime not only contains the general subject, also includes the doctor this kind of special subject, individual and unit can become the subject of such crime. Fourth, crime subjective aspect, the offender must have the subjective intent or negligence, the person knowing that their actions will produce harmful results and hope or indulge the happening of the result, or the offender shall be foreseen that their actions will produce harmful results due to negligence or is foreseen but trust can avoid. In terms of motive of the crime, the offender to implement the most crime is in order to obtain high economic benefits. For doctors, for example, due to the difficulty of the organ transplant operation, cost huge sums, the doctor can generally cut from the surgery.
Therefore, individual doctors in order to get the illegal income at compulsory harvesting or stealing other people's organs for transplantation. In terms of implementation of organ transplant unit, due to illegal harvesting, supply and smuggling of human organs can get high profits, some units tested, dare to engage in organ trafficking illegal business deals.

\section{B. The major form of human organ transplant crimes}

The crime is related to organ transplant organ transplantation of the floorboard of all sorts of serious harm social behavior. From the criminal object and the way of implementation and object of the crime, organ transplant crime in practice basically has the following several forms.

\section{1) Buying and selling human organs}

The behavior of the buying and selling human organs, that is, for profit, for the purpose of trading human organs, organs of legal content, the trading behavior of human organs, illegal behavior, should be cut into sin. From the point of view, the current countermeasures taken to this problem is not the same. As a crime, banned in some countries, such as Britain and France is the country's ban on organ trading legislation to clear ban on the behavior of the commercial trade in human organs. But the practice of some countries such as India to take is unchecked without interference. Several countries will be severely punished as a crime to the behavior. Buying and selling human organs, as a kind of crime refers to the purpose of making a profit, for the behavior of the commercial trade in human organs. China's criminal law does not prohibitive provisions on this crime." Buying and selling human organs is a derogatory to the person's social value, is about one thousand to sustain the existence and development of human society of some basic concepts such as life is priceless, health is priceless, etc.) severe shock.

As the development, it will eventually endanger the survival of human society. At the same time because of the characteristic of the human organ transplantation has high profits, also will stimulate the appetite for such crime. Therefore, for the sale of human organs has serious social harmfulness, is a kind of crime, should pass legislation to ban.

\section{2) Illegal harvesting the behavior of human organs}

Illegal harvesting refers to human organs "by violence, coercion, deception, theft and other illegal means, against the victim will harvest living donor organs for transplant behavior". The behavior of the victim's personal cause great harm, has serious social harmfulness, and actor's subjective vicious is very big, should be regarded as a crime.

\section{3) The smuggling of human organs}

At home and abroad in the current due to a serious shortage of source of organs, many criminals are dried up and smuggling of human organs. Trafficking in human organs is to constitute a crime: first: smuggling of human organs behavior violated the national customs supervision and control system, is the country's customs supervision's defiance. Secondly, the behavior of the smuggling of human organs is buying and selling human organs act expanded. This behavior is actually the human organs as commodity trading, only by a country's development in the multinational crime field. Again, the smuggling of human organs can cause a series of related 
serious harm social behavior, for example, illegal acquisition, illegal taking of human organs, etc. Therefore, smuggling is a kind of human organs than buying and selling human organs the behavior that is harmful to the larger society, is a kind of crime.

In recent years, the development of organ transplantation in our country is especially rapid, scale is growing. According to the national ministry of health statistics: only until the end of 2008, China had organ transplant more than 550000 cases, among them, more than 10000 cases of liver transplantation, more than 500000 cases of renal transplantation. In terms of quantity, organ transplantation in China is second only to the United States, ranking second in the world. However, although the medical practice in terms of organ transplantation in China has been far ahead in the world, but for the organ transplantation law research and legislation is almost in a blank state, this led to some parts of the human organs in our country is abused, while some crime on organ transplantation also occur frequently in our country. In October 1998, have taken place in Beijing at a big hospital in eyeball loss, a doctor which gathers the dead without authorization consent cornea used in organ transplantation. Although the case eventually end up in damages for the families of the dead spirit and court decisions, not treated as a crime, but a similar behavior of criminal sexual had to arouse people's attention. In addition, in the past for a long period of time, there is not subject to consent by the death and the use of its body or organs in our country also happened many times. In many cities of some hospitals or small corner of the square, often see some sell kidney "small ads", declare a healthy kidney can exchange with tens of thousands of dollars. In a familiarizing site, there are hundreds on such information about the sale of kidneys. As for does not have an organ transplant even the doctor didn't get professional qualification will give others provide transplant services, also in our country some of the media reports. These problems, poses challenges to our country law, especially the criminal law.

\section{CONCLUSIONS}

How to formulate a scientific and rational legal system especially the criminal law system, all from the organ transplant this new technology may have been the benefits have been limited in the proper purpose and legal procedures required by the limits, and objectively and not normal play to bring in the areas of organ transplantation, in response to the abuse of human organs and the crime with the challenge of organ transplantation, there is no doubt has become a contemporary lawmakers in particular contemporary criminal legislators facing a significant realistic subject.

\section{REFERENCES}

[1] Lanfang $\mathrm{Wu}$. The effectiveness analysis of legalization of ideological and political education [A]. Proceedings of the International Conference on Information Engineering and Education Science [C]. 2014

[2] Jiangyong Gong, Xu He. Liang Qichao's Sports Spirit on the Influence of Modern Sport Law [A]. 2011

[3] Jincai Xi. Study on the Remediation Model Construction of the Network Rumors [A]. Proceedings of 2014 2nd International Conference in Humanities, Social Sciences and Global Business Management (ISSGBM 2014 V25) [C]. 2014

[4] Jianjun Le. The Safety Accident That Is Caused by the Socialization of School Sports Facilities and Its Legal Analysis[A]. Proceedings of 2014 2nd International Conference in Humanities,Social Sciences and Global Business Management (ISSGBM 2014 V27) [C]. 2014

[5] Luyuan Yang. Research on the Inheritance and the Legal Protection of the folk Literature and Art[A]. Proceedings of 2015 3rd Asian Conference on the Social Sciences (Advances in Social and Behavioral Sciences Volume 15) [C]. 2015. 